\title{
PERFORMA REPRODUKSI IKAN BETOK (Anabas testudineus) BETINA DENGAN PEMBERIAN PAKAN BUATAN BERBAHAN BAKU TEPUNG KEONG MAS (Pomacea canaliculata)
}

\section{REPRODUCTIVE PERFORMANCE OF CLIMBING PERCH (Anabas Testudineus) FEMALES SUPLEMENTED FEED OF GOLDEN SNAIL (Pomacea Canaliculata) FLOUR AS RAW MATERIALS}

\author{
M. Masrur Ma'ruf ${ }^{1)}$, Ahmad Fahrul Syarif ${ }^{1)}$, Endang Bidayani ${ }^{1)}$ \\ ${ }^{1}$ Program Studi Akuakultur, Fakultas Pertanian, Perikanan dan Biologi, Universitas Bangka \\ Belitung, Indonesia \\ ${ }^{*)}$ alamat korespondensi: m.masrurmaruf10@gmail.com
}

\begin{abstract}
Abstrak
Ikan betok merupakan salah satu spesies ikan lokal yang potensial untuk dibudidayakan. Tujuan penelitian ini untuk mengkaji dan mengevaluasi pengaruh pemberian pakan berbahan baku keong mas (Pomacea canaliculata) terhadap tingkat kematangan gonad. Penelitian dilakukan pada bulan Juli - Agustus 2018. Ikan betok (A. testudineus) berasal dari tangkapan alam di perairan persawahan desa Rias Kecamatan Toboali Kabupaten Bangka Selatan. Ikan betok yang digunakan sebanyak 150 ekor dengan bobot $2 \pm 10$ gram. Perlakuan yang diberikan pakan buatan yang berbahan baku keong mas ( $P$. canaliculata) dengan kandungan protein pada pakan 32\%,34\%,36\%, 38\% dan kontrol menggunakan pakan komersil dengan kandungan protein $31-33 \%$. Hasil penelitian menunjukkan nilai Indeks Kematangan Gonad (IKG) dengan bobot gonad pada awal penelitian sebesar 0,5 gram. Setelah dilakukan perlakuan dengan pemberian pakan buatan berbahan baku tepung keong mas ( $P$. canaliculata), hasil uji statistik menunjukkan bawa kontrol berbeda nyata dengan perlakuan pada pengamatan GSI dengan kisaran nilai $16 \% \pm 0.02$ pada perlakuan P.38\%, HSI dengan kisaran nilai $8 \% \pm 0.01$ pada perlakuan P.38\%. Fekunditas ikan betok (A. testudineus) yang didapatkan pada hasil penelitian dengan kisaran 509 - 4.686 butir. Perkembangan tingkat kematangan gonad (TKG) awal penelitian (TKG II) setelah diberi pakan buatan berbahan baku keong mas ( $P$. canaliculata) meningkat dengan tingkat kematangan gonad mencapai tahap IV.
\end{abstract}

Kata Kunci : Ikan betok, keong mas, pematangan gonad, IKG, fekunditas, TKG.

\begin{abstract}
Climbing perch is one of the potential local fish species to be cultivated. The purpose of this study was to learn and evaluate the effect of feeding made from golden snail (Pomacea canaliculata) on the level of gonad maturity. The study was conducted in July - August 2018. The climbing perch (A. testudineus) originated from natural catchments in the rice fields of Rias village, Toboali Subdistrict, South Bangka Regency. The used fish are 150 fish with a weight of $2 \pm 10$ grams. The treatment given by artificial feed made from golden snail $(P$. canaliculata) with protein content in feed was $32 \%, 34 \%, 36 \%, 38 \%$ and control using commercial feed with a protein content of $31-33 \%$. The results showed the value of the Gonad Maturity Index (IKG) with gonad weight at the start of the study at 0.5 gram. After treatment with artificial feed made from golden snail $(P$. canaliculata) flour, the results of
\end{abstract}


statistical tests showed that the control was significantly different from the treatment in the GSI observation with a range of values of $16 \% \pm 0.02$ in treatment P.38\%, HSI with a value of $8 \% \pm 0.01$ in treatment P.38\%. Fecundity of climbing perch (A. testudineus) obtained in the results of the study with a range of $509 \pm 4,686$ items. The development of the initial gonad maturity (TKG) of the study (TKG II) after being given artificial feed made from golden snails (P. canaliculata) increased with the level of gonad maturity reaching stage IV.

Key words: Anabas testudineus, Pomacea canaliculata, gonad maturity, IKG, fecundity, TKG.

\section{PENDAHULUAN}

Ikan betok merupakan salah satu jenis ikan yang berada di perairan rawa dan sawah yang umumnya hampir ditemukan pada perairan rawa dan sawah di Indonesia. Ikan betok di Bangka Belitung selain ditemukan diperairan rawa dan sawah, ikan betok juga ditemukan pada perairan tergenang bekas galian tambang atau yang sering disebut masyarakat dengan sebutan kolong. Ikan betok umumnya hampir ditemukan pada penghujung musim kemarau atau hujan. Sebagian masyarakat di Bangka Belitung biasa menyebut ikan betok dengan sebutan ikan kepuyu. Ikan betok ini sangat digemari oleh masyarakat karena memiliki cita rasa yang enak serta memiliki daging yang tebal. Ikan ini juga bernilai ekonomis yang tinggi, harga ikan betok di pasar bisa mencapai Rp $25.000-40.000 / \mathrm{kg}$.

$$
\text { Kebutuhan yang tinggi }
$$

menyebabkan ikan betok banyak di cari dengan melakukan penangkapan di alam. Dampak dari penangkapan dialam dapat menyebabkan populasi ikan betok di alam semakin berkurang. Sedangkan di alam musim mijah sangat bergantung pada reproduksi dan respon perubahan lingkungan yang terjadi, Sementara itu perbandingan ikan jantan dan betina yang tertangkap di alam menunjukkan rasio kelamin tidak seimbang. Budidaya ikan betok saat ini masih sangat terbatas, karena masyarakat belum menguasai teknologi budidayanya serta informasinya belum memadai. Faktor yang sangat penting untuk menjamin kesinambungan ketersediaan benih untuk kegiatan budidaya tergantung pada kesiapan induk yang matang gonad, yaitu salah satunya ialah induk betina. Kesiapan ikan betina untuk menjadi calon indukan merupakan faktor penting dalam kegiatan budidaya, dikarenakan ikan betina akan menghasilkan telur dan benih. Menurut Kiran et al. (2013 diacu dalam Hariani dan Kusuma 2016) pengembangan kegiatan akuakultur dapat dilakukan dengan cara memanipulasi induk cepat matang gonad agar waktu reproduksi sesuai siklus produksinya. Selain sinyal dan respon lingkungan, pemberian pakan yang berprotein tinggi juga dapat dilakukan untuk mempercepat kematangan gonad.

Tujuan dari penelitian ini adalah untuk mengkaji pengaruh pemberian pakan buatan berbahan baku tepung keong mas terhadap performa reproduksi ikan betok betina dan mengevaluasi pemberian pakan buatan berbahan baku tepung keong mas dengan dosis yang berbeda terhadap performa reproduksi ikan betok betina.

\section{METODE PENELITIAN}

Penelitian ini dilaksanakan pada bulan Juli - Agustus 2018 dan bertempat di Hatchery jurusan Akuakultur Universitas Bangka Belitung, desa Balunijuk, Kecamatan Merawang, Kabupaten Bangka. Metode yang digunakan dalam penelitian ini menggunakan metode eksperimen.

Rancangan yang digunakan adalah Rancangan Acak Lengkap (RAL) tunggal yaitu pemberian pakan buatan keong mas 
dengan protein yang berbeda pada pematangan gonad ikan betok. Penelitian ini terdiri atas 5 perlakuan dan 3 kali ulangan. Perlakuan tersebut meliputi pemberian beberapa jenis pakan buatan keong mas dengan protein berbeda sebagai pakan pada ikan betok betina, yaitu sebagai berikut:

Perlakuan $A=$ Pemberian pakan Kontrol

Perlakuan $\mathrm{B}=$ Pemberian formulasi pakan buatan keong mas protein $32 \%$

Perlakuan $\mathrm{C}=$ Pemberian formulasi pakan buatan keong mas protein $34 \%$

Perlakuan $\mathrm{D}=$ Pemberian formulasi pakan buatan keong mas protein $36 \%$

Perlakuan $\mathrm{E}=$ Pemberian formulasi pakan buatan keong mas protein $38 \%$

Alat yang digunakan dalam penelitian ini adalah bak plastik berukuran $60 \times 35 \mathrm{~cm}$ sebanyak 15 buah, seser, timbangan digital, ember, selang sifon, instalasi aerasi, alat tulis, kamera, termometer, DO meter, $\mathrm{pH}$ meter dan ammonia checker.

Bahan yang digunakan dalam penelitian ini adalah ikan betok betina engan ukuran panjang rata-rata $3-15 \mathrm{~cm}$ dan kisaran bobot rata-rata 2 - 10 gram sebanyak 150 ekor hasil tangkapan alam di perairan desa Rias Kecamatan Toboali Kabupaten Bangka Selatan, pakan buatan berbahan baku keong mas.

\section{Prosedur Penelitian}

Persiapan Ikan Uji

Memilih ikan dengan ciri-ciri seksual sekunder ikan betok jantan yaitu secara morfologi ciri-ciri ikan jantan yaitu memiliki tubuh yang ramping dan panjang, warna badan agak cerah, sirip punggung lebih panjang, bagian bawah perut rata. Jika ikan betok jantan telah matang gonad, apabila di lakukan stripping pada bagian perut, akan keluar cairan sperma berwarna putih susu. Sedangkan ciri-ciri ikan betok betina yaitu memiliki ukuran tubuh yang

\section{Penentuan Dosis Formulasi Pakan dan} Pembuatan Pakan besar dari ikan betok jantan dan pada bagian perut melebar kesamping, warna badan agak gelap, sirip punggung lebih pendek, bagian bawah perut agak melengkung. Apabila ikan betok betina telah matang gonad dan di stripping pada bagian perut akan keluar butiran telur bewarna kuning dan alat kelamin berwarna kemerah-merahan (Burmansyah et al, 2013)

Setelah proses penyortiran selesai, selanjutnya akan dilakukan proses aklimatisasi selama 14 hari dalam wadah berupa bak fiber dengan ukuran $1 \times 2 \mathrm{~m}$ dan ikan diberikan pakan pelet komersil 781-1 pada pagi pukul 08.00 WIB dan sore pukul 16.00 WIB. Setelah proses aklimatisasi selesai, ikan akan ditebar sebanyak 10 ekor pada setiap wadah pemeliharaan. Proses pemeliharaan ikan betok dilakukan selama 45 hari dan diberikan pakan uji.

\section{Pembuatan Tepung Keong Mas}

Tepung keong mas dibuat berdasarkan pustaka Margono et al (1993), dalam pembuatan tepung keong mas, keong mas terlebih dahulu dikeluarkan lendir dan kotorannya dengan cara direndam dalam air mengalir selama dua hari, kemudian direndam menggunakan air garam dapur sebanyak $250 \mathrm{~g} / \mathrm{L}$ air. Lalu diaduk dan didiamkan selama \pm 30 menit sampai lendir keluar. Proses penggaraman dilakukan sebanyak dua kali. Pada penggaraman kedua menggunakan garam dapur sebanyak $150 \mathrm{~g} / \mathrm{L}$ air. Setelah itu direbus di air mendidih selama 20 menit, kemudian didinginkan lalu dipotong tipis. Selanjutnya potongan daging keong mas dikeringkan dibawah sinar matahari \pm 3 hari. Selanjutnya, setelah daging keong mas kering, daging tersebut akan ditepungkan menggunakan mesin blender. Hasil blender tersebut disaring menggunakan ayakan santan kelapa.

Penentuan dosis formulasi pembuatan pakan dan kandungan gizi dalam pakan menggunakan metode 
Pearson Square. Pearson Square merupakan cara untuk menghitung jumlah pakan yang diperlukan untuk memenuhi kebutuhan nutrisi ternak dan hewan lainnya. Pearson Square dapat digunakan untuk menentukan jumlah setiap bahan pakan yang diperlukan untuk mencapai tingkat gizi tertentu (National Research Council, 2001). Untuk melakukan penentuan formulasi pakan yaitu yang pertama dilakukan adalah menghitung kebutuhan bahan untuk membuat $1 \mathrm{~kg}$ pakan dengan kandungan protein pada bahan yaitu; 1. Tepung keong mas $(51,8 \%), 2$. Tepung kedelai $(38 \%), 3$. Dedak padi $(12 \%)$, dan 4 . Tepung tapioka (2\%) dan untuk menghitung protein pakan perlakuan yang telah ditentukan yaitu $32 \%$, $34 \%, 36 \%$ dan $38 \%$. Untuk menghitung kebutuhan bahan tersebut, dihitung menggunakan metode Pearson Square. Kebutuhan bahan untuk $1 \mathrm{~kg}$ pakan disajikan dalam (Tabel 1).

Tabel 1. Kebutuhan bahan untuk membuat $1 \mathrm{~kg}$ pakan

\begin{tabular}{ccccc}
\hline \multirow{2}{*}{$\begin{array}{c}\text { Protein } \\
\text { Target }\end{array}$} & \multicolumn{4}{c}{ Kebutuhan Bahan dalam 1 Kg Pakan } \\
\cline { 2 - 5 } & TKM & TKD & DPI & TPI \\
& $(51,8 \%)$ & $(38 \%)$ & $(12 \%)$ & $(2 \%)$ \\
\hline $32 \%$ & $182,5 \mathrm{~g}$ & $547,5 \mathrm{~g}$ & $87 \mathrm{~g}$ & $173,3 \mathrm{~g}$ \\
$34 \%$ & $197,5 \mathrm{~g}$ & $592,5 \mathrm{~g}$ & $67 \mathrm{~g}$ & $133,3 \mathrm{~g}$ \\
$36 \%$ & $210 \mathrm{~g}$ & $630 \mathrm{~g}$ & $50 \mathrm{~g}$ & $10 \mathrm{~g}$ \\
$38 \%$ & $225 \mathrm{~g}$ & $675 \mathrm{~g}$ & $30 \mathrm{~g}$ & $60 \mathrm{~g}$ \\
\hline
\end{tabular}

Keterangan :

TKM = Tepung Keong Mas;

TKD = Tepung Kedelai;

DPI = Dedak Padi;

TPI $=$ Tepung Tapioka

Pembuatan pakan dimulai dengan menimbang bahan baku pakan sesuai dengan formulasi yang telah ditentukan. Formulasi yang digunakan dalam pembuatan pakan ini adalah tepung keong mas, tepung kedelai, tepung tapioka, dedak padi halus. Seluruh bahan dicampur kemudian ditambahkan air dan diaduk hingga tercampur merata. Bahan pakan yang telah tercampur dan membentuk padatan dicetak menggunakan mesin penggiling pakan. Hasil cetakan di potong kecil-kecil, lalu dijemur dibawah terik matahari hingga kering.

\section{Persiapan wadah dan media penelitian}

Wadah yang digunakan pada penelitian berupa bak plastik dengan ukuran $60 \mathrm{~cm} \times 35 \mathrm{~cm}$. Proses penggunaan wadah dilakukan pencucian terlebih dahulu sampai wadah bersih dan kering kemudian isi air sebanyak 20 L dengan ketinggian 11 $\mathrm{cm}$. Wadah yang telah diisi air dipasang aerator dan dilengkapi dengan batu aerasi yang beroperasi selama 24 jam.

\section{Sampling}

Pengukuran bobot, panjang ikan dan tingkat kematangan gonad ikan betok dilakukan dengan menggunakan penggaris, timbangan digital dan dibedah. Penghitungan bobot, panjang dan tingkat kematangan gonad awal dilakukan sebelum penebaran di dalam wadah pemeliharaan dengan mengambil sampel sebanyak 30 ekor. Pengamatan tingkat kematangan gonad pada ikan betok betina meliputi pengisian ovarium dan warna telur yang dilakukan berdasarkan Effendie (1979). Setiap hari selama pemeliharaan dilakukan pencatatan jumlah dan bobot ikan yang mati. Pemberian pakan 
dilakukan setiap hari sebanyak 3 kali dalam sehari, pakan diberikan sekenyangkenyangnya (at sattion) pada ikan pada pagi hari, siang hari dan sore hari.

Setiap 15 hari pemeliharaan dilakukan sampling pada bobot, panjang, dan tingkat kematangan gonad ikan betok betina dengan mengambil 30\% sampel dari populasi ikan betok/wadah pemeliharaan. Setelah 45 hari pemeliharaan dilakukan penghitungan fekunditas telur, gonado somatic index (GSI), hepato somatic index (HSI), pertumbuhan bobot mutlak, panjang mutlak, indeks kematangan gonad, kelulushidupan, spesific growth rate (SGR), dan tingkat kebuntingan. Kualitas air meliputi suhu, pH, DO (Disolved Oxygen), TAN (Total Ammonia Nitrogen) yang diukur setiap 7 hari sekali.

\section{Fekunditas}

Fekunditas dihitung dengan metode gravimetrik Effendie (1979) sebagai berikut :

Keterangan :

$$
\mathrm{F}=\frac{\mathrm{G} \times \mathrm{V} \times \mathrm{X}}{\mathrm{Q}}
$$

$\mathrm{F}:$ Fekunditas

$\mathrm{G}:$ Berat gonad (g);

$\mathrm{V}$ : Isi pengenceran (cc);

$\mathrm{X}$ : Jumlah telur tiap cc;

$\mathrm{Q}$ : Berat telur contoh (g);

\section{GSI (Gonado Somatic Index)} berikut :

Menurut Effendie (2002) sebagai

$$
\text { GSI } \%=\text { GSI } \%=\frac{\mathrm{Wg}}{\mathrm{Wt}-\mathrm{Wg}} \times 100
$$

\section{Keterangan :}

GSI : Gonado Somatic Index;

$\mathrm{Wg}$ : berat gonad (g) dan

Wt : berat tubuh $(\mathrm{g})$;

\section{HSI (Hepato Somatic Index)}

Rumus hitung Hepato Somatic Index (HSI) menurut Effendie (2002) sebagai berikut :

$$
\text { HSI }(\%)=\operatorname{HSI}(\%)=\frac{W h}{W t-W h} \times 100
$$

Keterangan :
HSI = Hepato Somatic Index;

$\mathrm{Wh}=$ berat hepar $(\mathrm{g})$;

$\mathrm{Wt}=$ berat tubuh $(\mathrm{g})$;

\section{Pertumbuhan Bobot Mutlak (PBM)}

Pertumbuhan bobot mutlak menggunakan rumus Effendie (1979) sebagai berikut :

$$
\mathrm{PBM}=\overline{\mathrm{W}} \mathrm{t}-\overline{\mathrm{W}}_{0}
$$

Keterangan :

PBM = Pertumbuhan bobot mutlak (g)

$\overline{\mathrm{W}}_{\mathrm{t}}=$ Bobot ikan akhir pemeliharaan $(\mathrm{g})$

$\overline{\mathrm{W}}_{0}=$ Bobot ikan awal pemeliharaan $(\mathrm{g})$

\section{Pertumbuhan Panjang Mutlak (PPM)}

Pertumbuhan Panjang mutlak

menggunakan rumus Effendie (1979)

sebagai berikut :

$$
\mathrm{PPM}=\overline{\mathrm{L}} 2-\overline{\mathrm{L}} 1 ;
$$

Keterangan :

$\mathrm{PPM}=$ Pertumbuhan panjang mutlak $(\mathrm{cm}) ; \overline{\mathrm{L}}_{2}$ $=$ Rata-rata panjang akhir $(\mathrm{cm})$;

$\overline{\mathrm{L}}_{1}=$ Rata-rata panjang awal $(\mathrm{cm})$.

\section{Kelulushidupan}

Kelulushidupan menggunakan rumus Effendi (2006) sebagai berikut :

Keterangan :

$$
\mathrm{SR}=\frac{\mathrm{Nt}}{\mathrm{N} 0} \times 100 \%
$$

$\mathrm{SR}=$ Tingkat kelangsungan hidup (\%)

$\mathrm{N}_{\mathrm{t}}=$ Jumlah ikan hidup pada akhir pemeliharaan (ekor)

$\mathrm{N}_{0}=$ Jumlah ikan pada awal pemeliharaan (ekor);

\section{SGR (Specific Growth Rate)}

(1987) :

$$
\text { Berdasarkan rumus Huisman }
$$

Keterangan :

$$
\mathrm{SGR}=\left[\sqrt[\mathrm{t}]{\frac{\mathrm{Wt}}{\mathrm{W} 0}}-1\right] \times 100 \%
$$

SGR = Laju Pertumbuhan Spesifik (\%);

$\mathrm{Wt}=$ Berat rata-rata ikan uji akhir penelitian (g);

$\mathrm{W} 0=$ Berat rata-rata ikan uji awal penelitian $(\mathrm{g})$;

$\mathrm{t}=$ lama waktu penelitian (hari) ; 


\section{Tingkat Kebuntingan}

Tingkat kebuntingan diamati pada morfologi bagian perut induk ikan betina yang membesar, melebar kesamping dan berisi telur yang diketahui dengancara mengurut (stripping) pada bagian berut ikan tersebut. Induk yang bunting adalah induk yang memiliki telur saat dilakukan stripping dan akan mengelurkan telur pada bagian lubang urogenitalnya. Cara untuk menghitung persentase tingkat kebuntingan adalah dengan membandingkan jumlah ikan yang bunting dengan jumlah ikan sampel. Tingkat kebuntingan ikan dapat dihitung

\section{HASIL}

\section{Aspek Reproduksi Ikan Betok Seksualitas Ikan Betok}

Ciri-ciri seksual sekunder ikan betok (Gambar 1 dan 2.) yaitu ikan betok jantan yaitu memiliki tubuh yang ramping dan panjang, warna badan agak cerah, sirip punggung lebih panjang, bagian bawah perut rata. Jika ikan betok jantan telah matang gonad, apabila di lakukan stripping pada bagian perut, akan keluar cairan sperma berwarna putih susu. Sedangkan

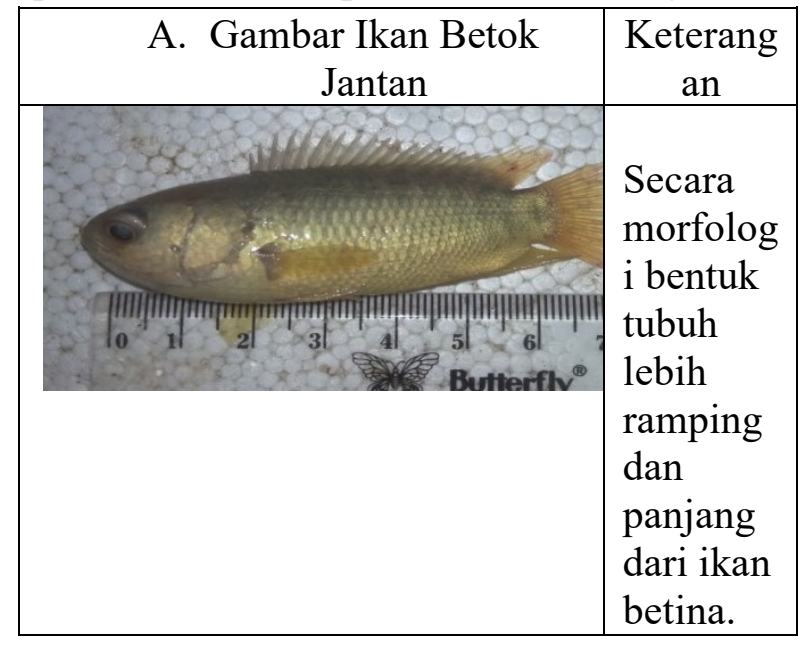

menggunakan persamaan menurut Hanifah (2010) sebagai berikut :

Tingkat Kebuntingan $=\frac{\sum \text { ikan bunting }}{\sum \text { ikan sampel }} \times 100 \%$

\section{Kualitas Air}

Parameter kualitas air yang diukur meliputi suhu, pH, DO (Disolved Oxygen), TAN (Total Ammonia Nitrogen). Pengukuran suhu dengan menggunakan termometer, pengukuran $\mathrm{pH}$ dilakukan dengan menggunakan $\mathrm{pH}$ meter, sedangkan untuk pengecekan dari DO (Disolved Oxygen), TAN (Total Ammonia Nitrogen) dianalisis menggunakan alat yaitu Ammonia Checker.

ciri-ciri ikan betok betina yaitu memiliki ukuran tubuh yang besar dari ikan betok jantan dan pada bagian perut melebar kesamping, warna badan agak gelap, sirip punggung lebih pendek, bagian bawah perut agak melengkung. Apabila ikan betok betina telah matang gonad dan di stripping pada bagian perut akan keluar butiran telur bewarna kuning dan alat kelamin berwarna kemerah-merahan (Burmansyah et al, 2013).

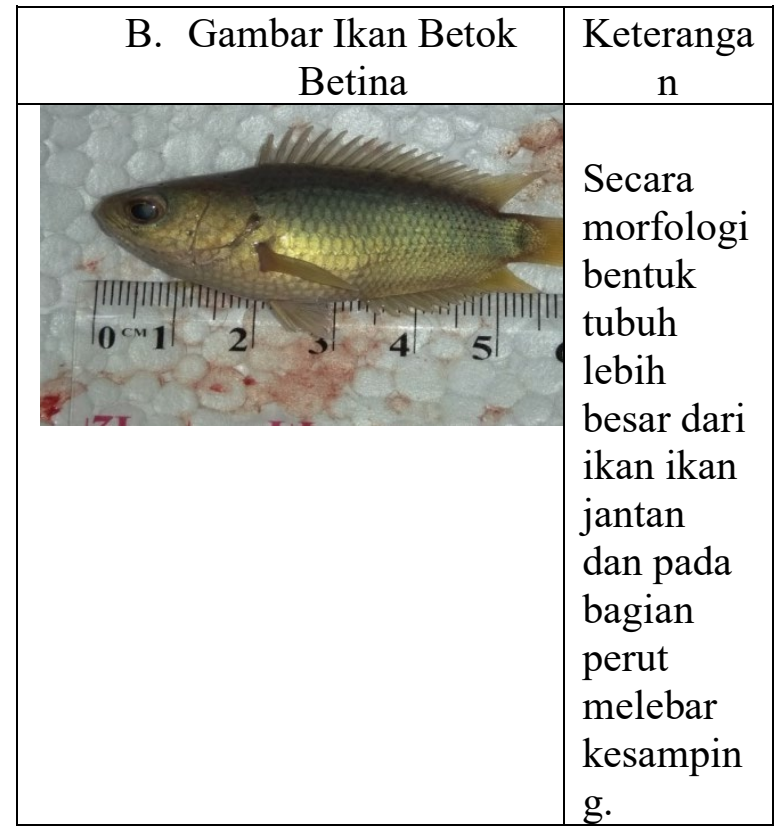



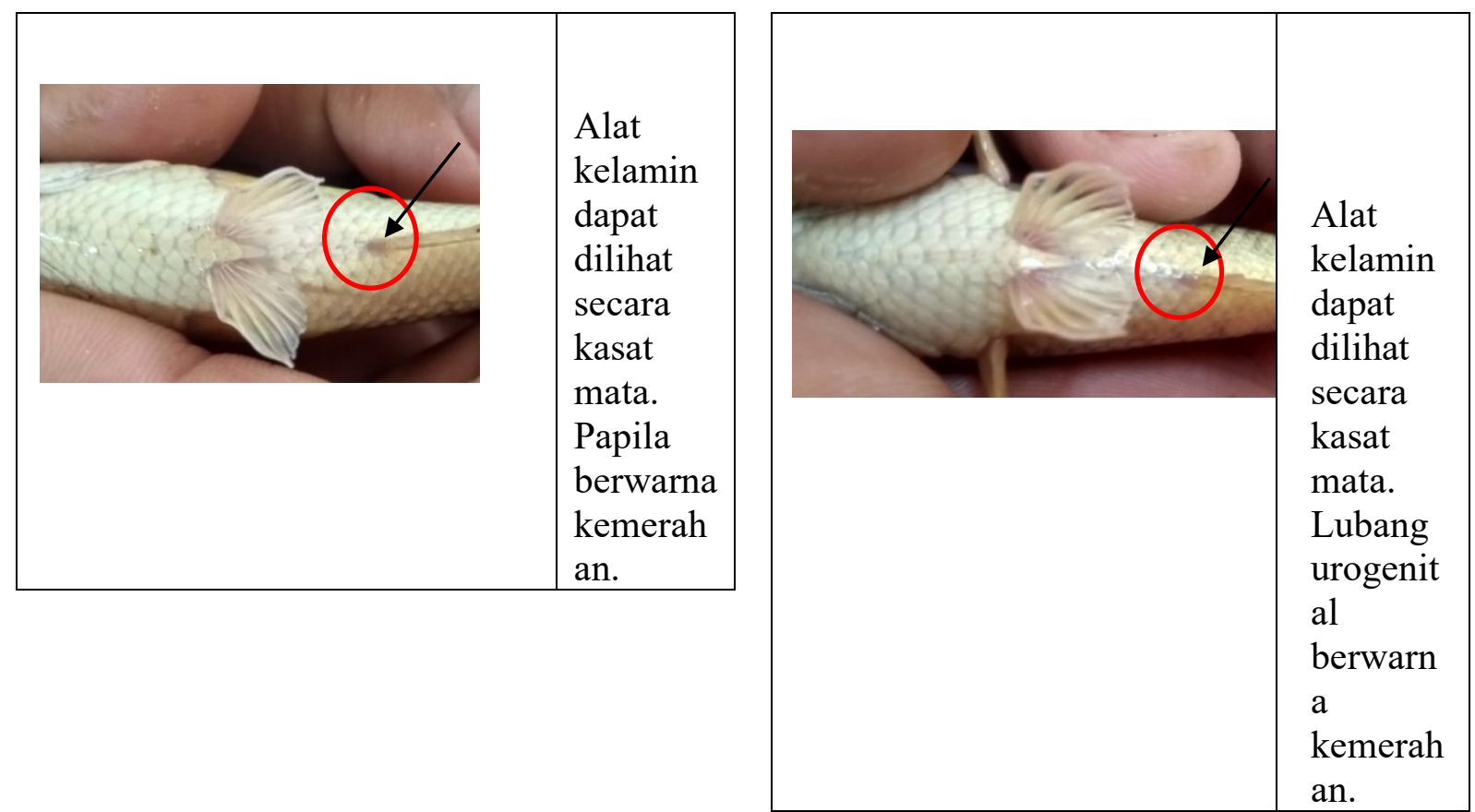

Gambar 1. Ciri-ciri morfologi dan kelamin ikan betok

Sumber : (Dokumentasi Pribadi, 2018)

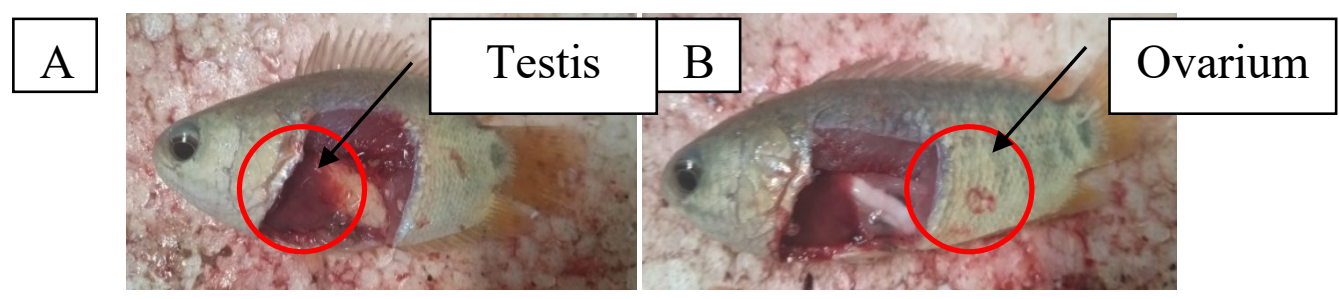
a. Ikan betok jantan
b. Ikan betok betina

Gambar 2. Anatomi ikan betok

Sumber : (Dokumentasi Pribadi, 2018)

Tingkat Kematangan Gonad Ikan Betok (TKG)

Tingkat kematangan gonad (TKG) adalah tahap-tahap tertentu perkembangan gonad sebelum dan sesudah ikan memijah. Penentuan tingkat kematangan gonad antara lain dengan mengamati perkembangan gonad (Effendie, 1997 dalam Tester dan Takata, 1953).

Berikut merupakan hasil dari pengamatan Tingkat Kematangan Gonad Ikan Betok betina yang disajikan pada Tabel 2.

Tabel 2. Hasil Pengamatan Tingkat Kematangan Gonad Ikan Betok Betina

\begin{tabular}{|c|c|c|}
\hline TKG & Gambar Gonad & \multicolumn{1}{|c|}{ Keterangan } \\
\hline I & & $\begin{array}{l}\text { Gonad sangat kecil seperti benang dan } \\
\text { transparan. Penampang gonad bulat } \\
\text { dengan warna kemerah-merahan. }\end{array}$ \\
\hline
\end{tabular}




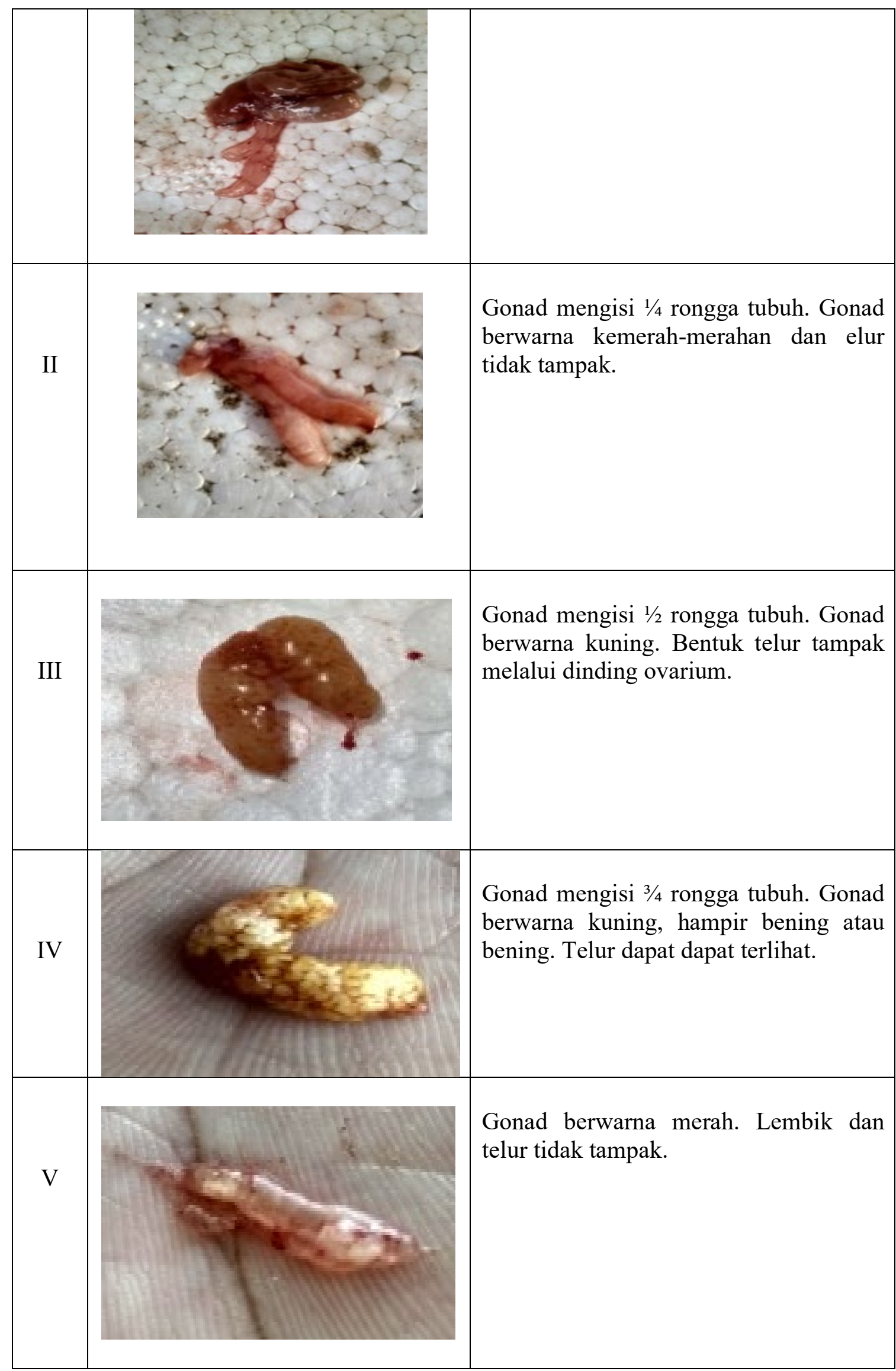

Dari hasil pengamatan pada awal penelitian kondisi ikan pada tahap TKG I dan II, sedangkan pada hari terakhir pengamatan di peroleh bahwa 
perkembangan gonad ikan meningkat pada setiap perlakuan dan kontrol. Pada hari ke 45 pada perlakuan P.34\% dan P.36\% ditemukan ikan telah memasuki TKG IV dengan ciri-ciri gonad berwarna kuning dan telur dapat terlihat dan pada hari ke 45 pada $\mathrm{P} .38 \%$ ditemukan ikan yang telah memasuki TKG V dengan ciri-ciri gonad berwarna merah, lembik dan telur tidak tampak. Sedangkan pada perlakuan P.32\% dan Kontrol pada saat dilakukan pembedahan ikan masih dalam fase TKG III dengan ciri-ciri gonad berwarna kuning, telur sudah mulai terlihat, namun masih terdapat cairan pada butiran telur.

yang disajikan dalam bentuk grafik pada Gambar 3.

\section{Gonado Somatic Index}

Berikut merupakan hasil dari pengamatan Gonado Somatic Index (GSI)

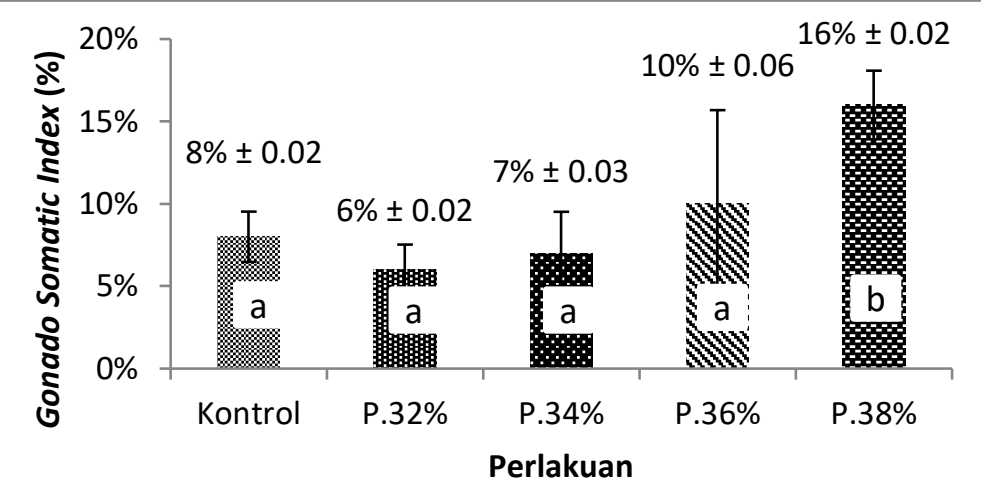

Gambar 3. Grafik nilai hasil pengamatan Gonado Somatic Index (GSI) ikan betok selama pemeliharaan

Sumber : (Data Primer, 2018)

Dari hasil pengamatan Gonado Somatic Index, hasil pengamatan bahwa perlakuan yang diberikan pakan buatan berbahan

\section{Hepato Somatic Index (HSI)}

Berikut merupakan hasil dari pengamatan Hepato Somatic Index (HSI) baku tepung keong mas terdapat perbedaan dengan kontrol $(\mathrm{P}<0,05)$ dengan kisaran nilai $16 \% \pm 0.02$ pada perlakuan P. $38 \%$.

yang disajikan dalam bentuk grafik pada Gambar 4.

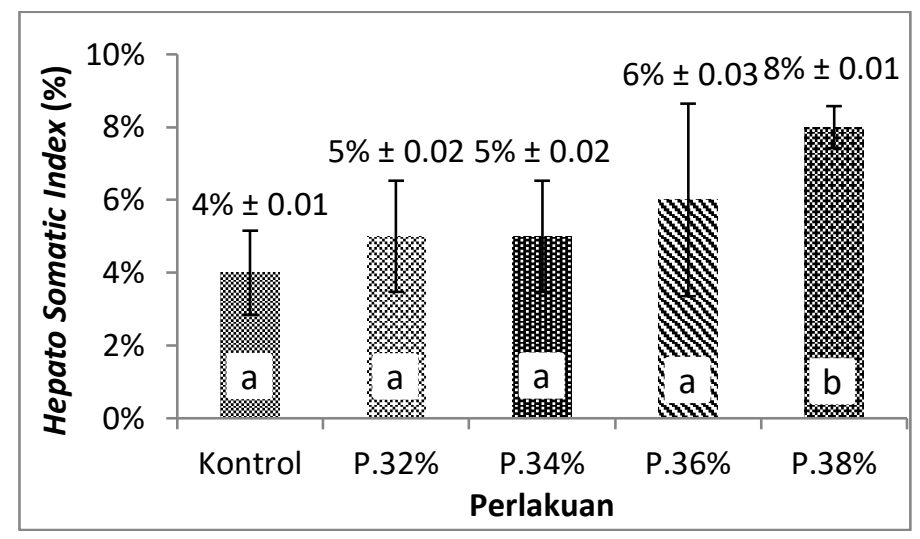

Gambar 4. Grafik nilai hasil pengamatan Hepato Somatic Index (HSI) ikan betok selama pemeliharaan Sumber : (Data Primer, 2018) 
Dari hasil pengamatan Hepato Somatic Index, bahwa perlakuan yang diberikan pakan buatan berbahan baku tepung keong mas menunjukkan perbedaan

\section{Tingkat Kebuntingan Ikan}

Berikut merupakan hasil dari pengamatan tingkat kebuntingan ikan
$(\mathrm{P}<0,05)$ dengan kisaran nilai HSI $8 \% \pm$ 0.01 pada perlakuan P. $38 \%$.

betok yang disajikan dalam bentuk tabel dan grafik pada Tabel 4 dan Gambar 5.

Tabel 4. Hasil Pengamatan Tingkat Kebuntingan Ikan

\begin{tabular}{lccccc}
\hline \multicolumn{5}{c}{ Tingkat Kebuntingan Ikan (\%) } \\
\hline Perlakuan & Kontrol & P.32\% & P.34\% & P.36\% & P.38\% \\
\hline Rata-rata & $7 \%$ & $9 \%$ & $7 \%$ & $7 \%$ & $7 \%$ \\
Stdev & 0,03 & 0,03 & 0,03 & 0,03 & 0,03 \\
\hline \multicolumn{5}{c}{ Sumber : (Data Primer, 2018) }
\end{tabular}

Dari tabel pengamatan diatas diperoleh hasil rata-rata pada pengamatan Tingkat Kebuntingan ikan dengan rata-rata jumlah ikan bunting per pengamatan

tertinggi yaitu pada P.32\% dengan rata-rata $9 \%$ dan diikuti oleh perlakuan P.34\%,P.36\% dan kontrol dengan rata-rata berkisar $7 \%$.

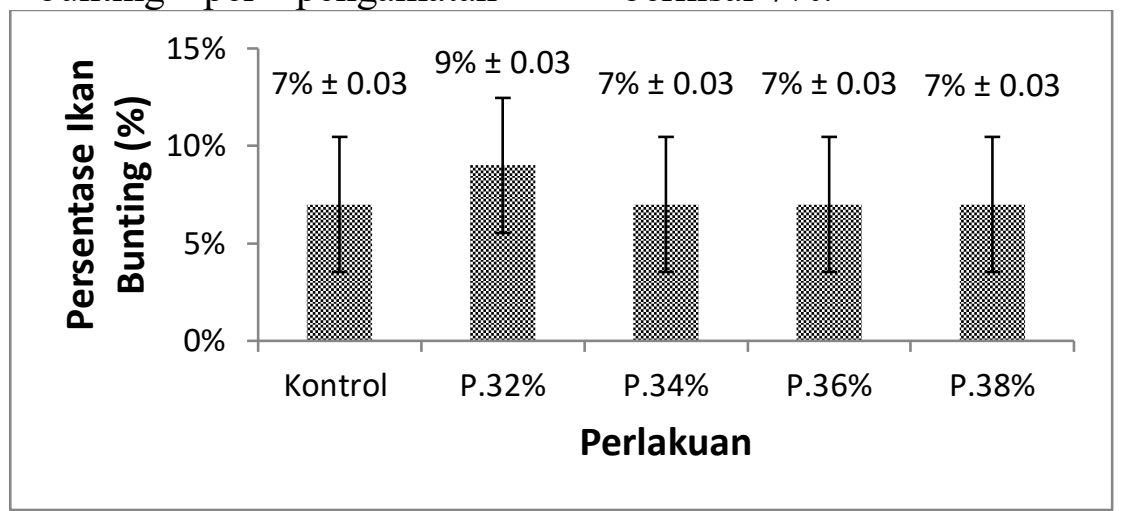

Gambar 5. Grafik nilai hasil pengamatan Tingkat Kebuntingan Ikan Sumber : (Data Primer, 2018)

Dari hasil pengamatan Tingkat Kebuntingan Ikan pada hari terakhir penelitian bahwa peningkatan tingkat kebuntingan ikan stagnan pada semua perlakuan, hal ini dikarenakan ikan telah mencapai fase ke 4 atau siap memijah dengan ciri-ciri warna telur sudah

\section{Fekunditas}

Fekunditas merupakan jumlah telur ikan betina yang masak sebelum dikeluarkan pada waktu ikan akan memijah. Fekunditas rata-rata ikan betok betina bekisar antara 2.544 butir telur per kekuningan dan butiran telur terlihat jelas. Pada pengamatan ada ditemukannya ikan yang telah memasuki fase ke 5 yaitu salin yang ditemukan pada perlakuan P.38\% dengan ciri-ciri ovari memerah dan masih terdapat beberapa sisa butir telur di dalam ovari.

ikan dengan TKG III - IV. Berikut merupakan hasil dari pengamatan fekunditas yang disajikan dalam bentuk tabel dan grafik. 
Jurnal Perikanan (2020) Volume 10. No. 2 : 92-111

DOI : https://doi.org/10.29303/jp.v10i2.130

Tabel 5. Hasil Pengamatan Fekunditas

\begin{tabular}{cccccc}
\hline TKG & $\begin{array}{c}\text { Kisaran } \\
\text { Bobot Tubuh } \\
(\mathbf{g})\end{array}$ & $\begin{array}{c}\text { Kisaran Bobot } \\
\text { Gonad (g) }\end{array}$ & $\begin{array}{c}\text { Kisaran } \\
\text { Fekunditas } \\
\text { (butir) }\end{array}$ & $\begin{array}{c}\text { Rata-rata } \\
\text { Fekunditas } \\
\text { (butir) }\end{array}$ & $\begin{array}{c}\text { Jumlah } \\
\text { Sampel } \\
\text { (ekor) }\end{array}$ \\
\hline III - IV & $6.60-16.30$ & $0.14-1.54$ & $533-14.000$ & 2.544 & 30 \\
\hline \multicolumn{5}{c}{ Sumber : (Data Primer, 2018) }
\end{tabular}

Dari tabel di atas bahwa fekunditas ikan betok betina dengan kisaran bobot tubuh 6.60 - 16.30 gram, bobot gonad berkisar antara $0.14-1.54$ gram, fekunditas berkisar antara $533-14.000$ butir telur dengan rata-rata 2.544 butir telur per ikan betina.
Berikut merupakan gambar dari grafik hubungan antara fekunditas dengan bobot gonad dan bobot tubuh ikan betok betina, yang disajikan pada (Gambar 6 dan 7).

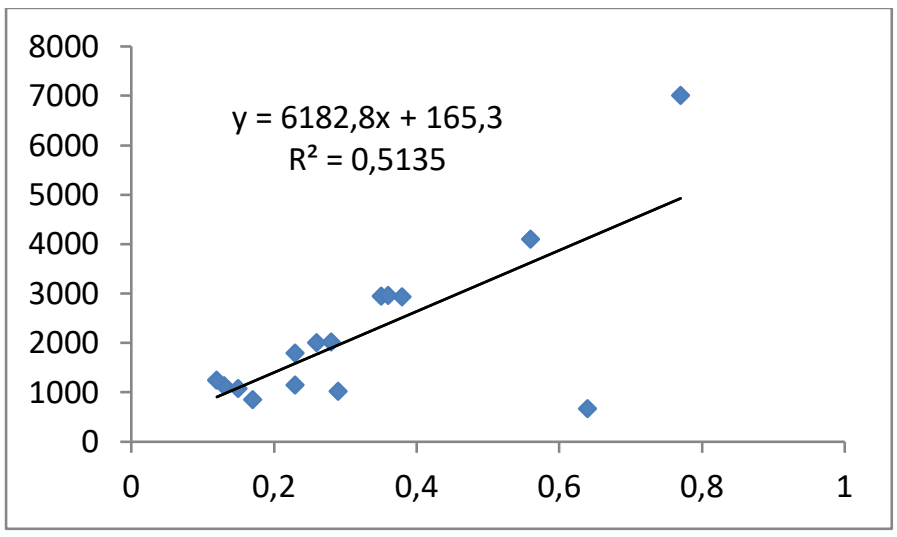

Gambar 6. Hubungan fekunditas dengan bobot gonad ikan betok Sumber : (Data Primer, 2018)

Dari grafik diatas menunjukkan bahwa fekunditas ikan betok menunjukkan adanya hubungan dengan bobot gonad ikan dimana nilai $\mathrm{R}^{2}=0,513$.

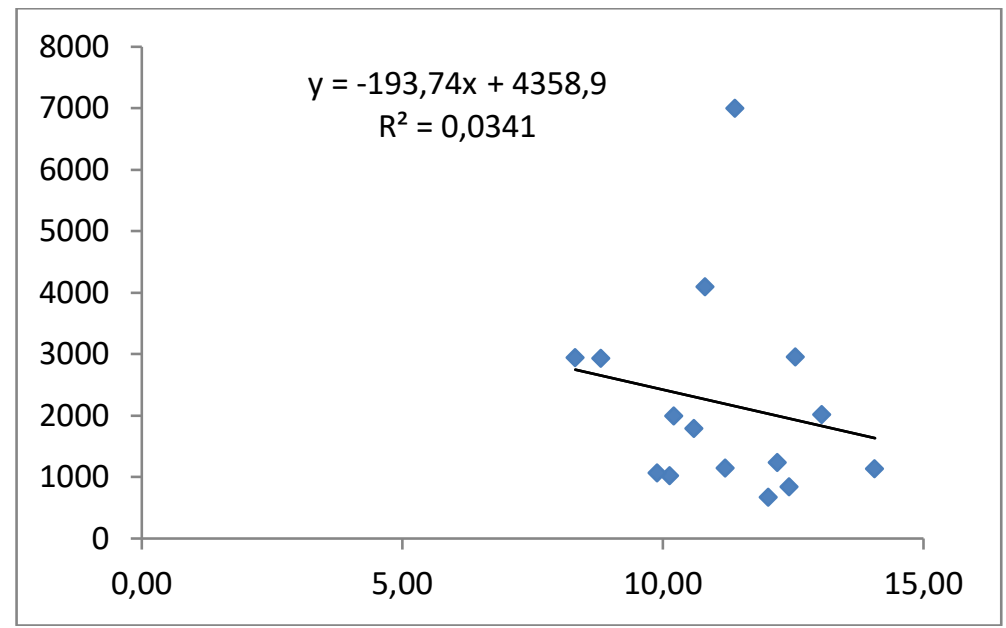

Gambar 7. Hubungan fekunditas dengan bobot tubuh ikan betok Sumber : (Data Primer, 2018) 
Dari grafik diatas menunjukkan bahwa fekunditas ikan betok menunjukkan

Pertumbuhan

Pertumbuhan Bobot Mutlak

Berikut merupakan hasil dari pengamatan Pertumbuhan Bobot Mutlak tidak adanya hubungan dengan bobot tubuh ikan dimana nilai $\mathrm{R}^{2}=0,34$.

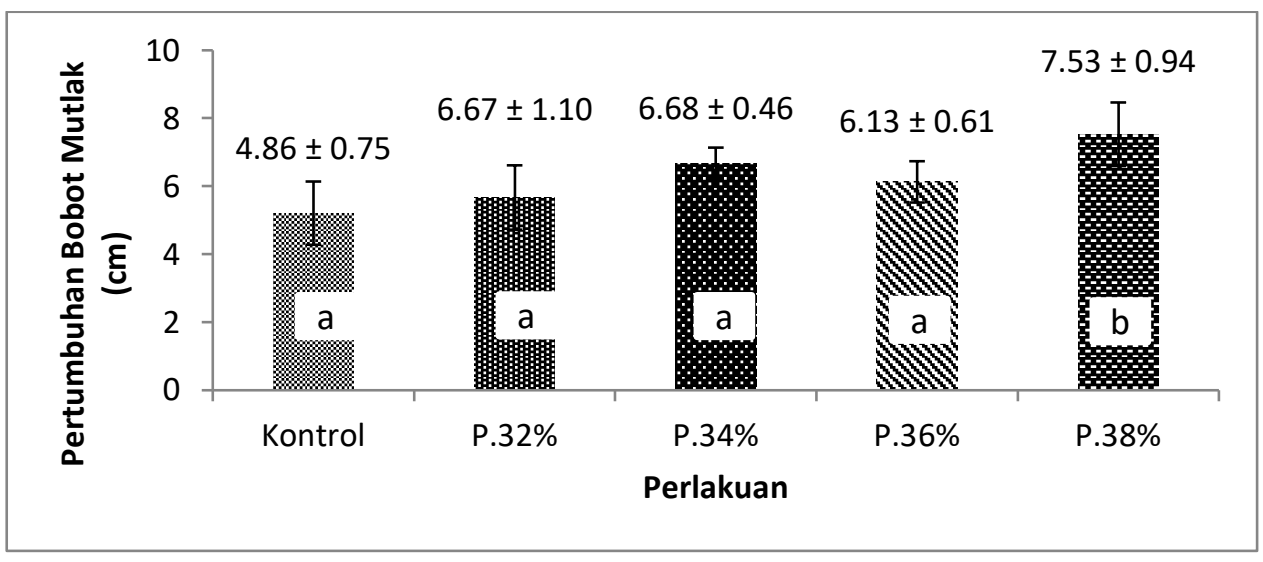

Gambar 8. Grafik Nilai Hasil Pengamatan Pertumbuhan Bobot Mutlak Sumber : (Data Primer, 2018)

Dari pengamatan diatas diperoleh bahwa perlakuan yang diberikan pakan buatan berbahan baku tepung keong mas pada pengamatan pertumbuhan bobot yang disajikan dalam bentuk grafik pada Gambar 8 .

\section{Pertumbuhan Panjang Mutlak}

Berikut merupakan hasil dari pengamatan Pertumbuhan Panjang Mutlak

mutlak menunjukkan adanya perbedaan antar perlakuan $(\mathrm{P}<0,05)$ dengan kisaran nilai $7.53 \mathrm{~g} \pm 0.94$ pada perlakuan P.38\%.

yang disajikan dalam bentuk grafik pada Gambar 9.

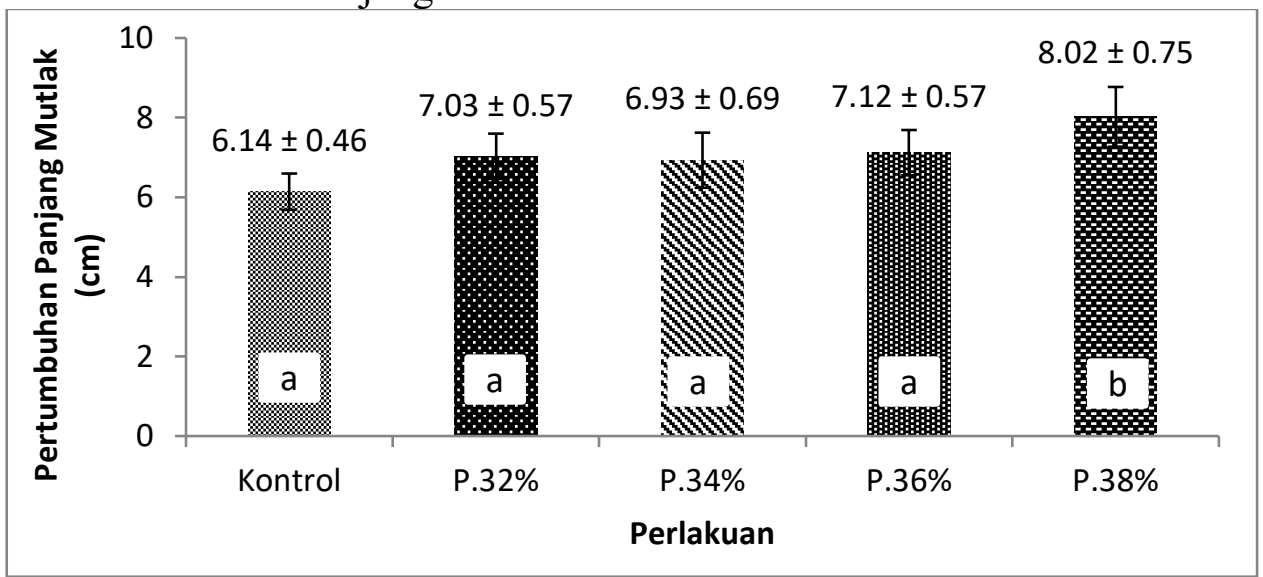

Sumber : (Data Primer, 2018)

Gambar 9. Grafik Nilai Hasil Pengamatan Pertumbuhan Panjang Mutlak

Dari pengamatan diatas diperoleh bahwa perlakuan yang diberikan pakan buatan berbahan baku tepung keong mas pada pengamatan pertumbuhan panjang mutlak menunjukkan perbedaan antar 
Jurnal Perikanan (2020) Volume 10. No. 2 : 92-111

DOI : https://doi.org/10.29303/jp.v10i2.130

perlakuan $(\mathrm{P} 0,05)$ dengan kisaran nilai

$8.02 \mathrm{~cm} \pm 0.75$ pada perlakuan P. $38 \%$.

Laju Pertumbuhan Harian

Berikut merupakan hasil dari

yang disajikan dalam bentuk grafik pada pengamatan Laju Pertumbuhan Harian

Gambar 10.

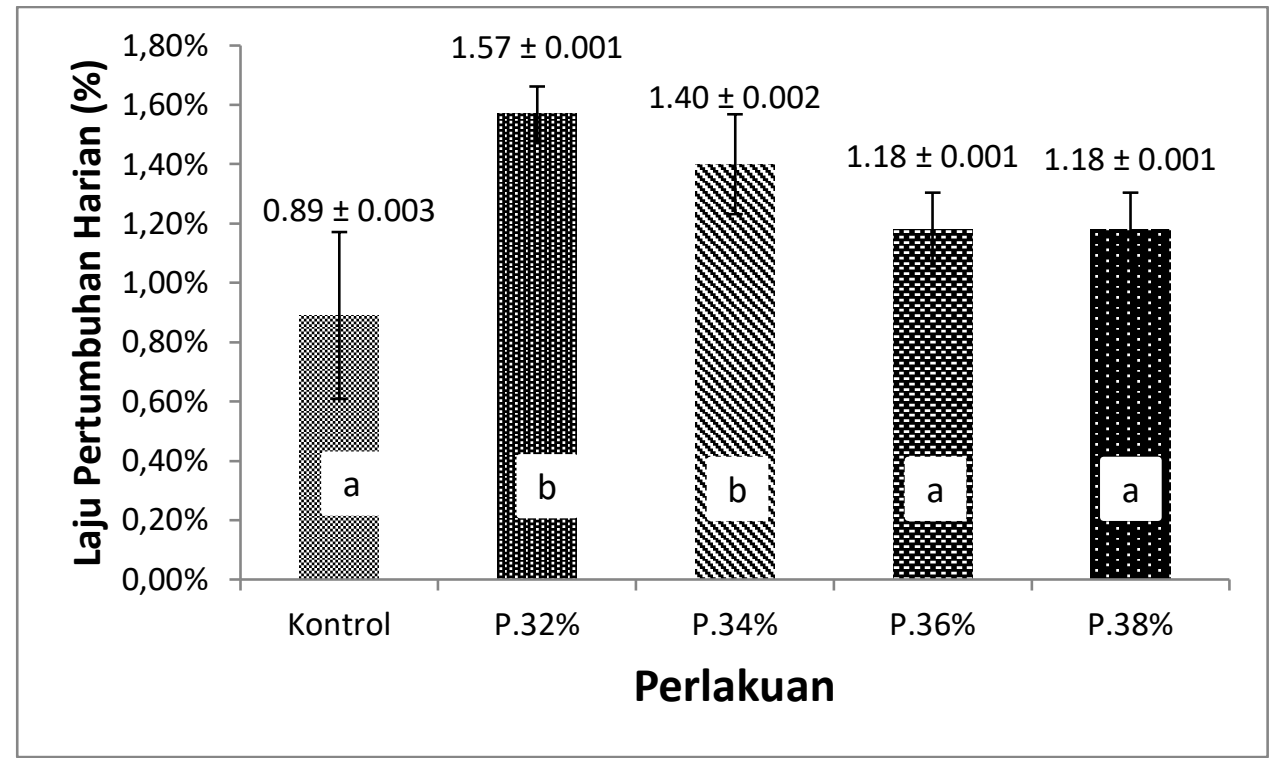

Gambar 10. Grafik Nilai Hasil Pengamatan Laju Pertumbuhan Harian Sumber : (Data Primer, 2018)

Dari hasil pengamatan laju pertumbuhan harian bahwa perlakuan yang diberikan pakan buatan berbahan baku tepung keong mas pada pengamatan laju

\section{Kualitas Air}

Berikut merupakan hasil dari pengamatan Kualitas Air yaitu Suhu, pH, pertumbuhan harian menunjukkan adanya perbedaan antar perlakuan $(\mathrm{P}<0,05)$ pada P.32\% dan P.34\% dengan kisaran nilai $1.57 \mathrm{~g} \pm 0.001$ dan $1.40 \mathrm{~g} \pm 0.002$.

Oksigen Terlarut dan Total Ammonia Nitrogen $(T A N)$ yang disajikan dalam bentuk tabel pada Tabel 8 .

Tabel . Hasil pengamatan rata-rata kualitas air selama 45 hari penelitian

\begin{tabular}{ccccc}
\hline \multicolumn{5}{c}{ Parameter Pengamatan } \\
\hline Perlakuan & Suhu $\left({ }^{\circ} \mathrm{C}\right)$ & $\mathrm{pH}$ & Oksigen Terlarut $(\mathrm{mg} / \mathrm{L})$ & TAN $(\mathrm{mg} / \mathrm{L})$ \\
\hline Kontrol & 30 & 6,24 & 5,6 & 0,29 \\
P.32\% & 30 & 6,58 & 5,6 & 0,22 \\
P.34\% & 30 & 6,65 & 5,6 & 0,20 \\
P.36\% & 30 & 6,73 & 5,6 & 0,16 \\
P.38\% & 30 & 6,55 & 5,6 & 0,16 \\
\hline
\end{tabular}

Sumber : (Data Primer, 2018)

Berdasarkan hasil pengamatan Kualitas Air diperoleh bahwa rentang suhu selama penelitian yaitu berkisar antara $30^{\circ} \mathrm{C}, \mathrm{pH}$ berkisar antara $6,24-6,73$,
Oksigen terlarut berkisar antara $5,6 \mathrm{mg} / \mathrm{L}$ dan Total Ammonia Nitrogen ( TAN ) berkisar antara $0,16-0,29 \mathrm{mg} / \mathrm{L}$. 


\section{PEMBAHASAN}

\section{Aspek Reproduksi Ikan Betok Seksualitas Ikan Betok}

Betok (Anabas testudineus Bloch) bersifat ovipar, dapat memijah sepanjang tahun dengan puncak pemijahannya pada musim hujan dengan puncaknya pada bulan oktober hingga desember, telur-telur mengapung bebas. Ikan dengan kisaran bobot tubuh 15 sampai 110 gram dan bobot gonad 2,42 sampai 15,96 gram mempunyai jumlah telur (fekunditas) antara 4.882 hingga 19.248 butir (www.dkp.go.id).

Berdasarkan hasil pengamatan yang dilakukan bahwa ikan betok betina yang telah matang gonad mempunyai bentuk tubuh yang lebih besar jika dibandingkan dengan ikan betok jantan yang matang gonad. Selain itu pada ikan betok betina yang telah matang gonad pada bagian perut ikan akan melebar kesamping dan jika di lakukan pengurutan (stripping) pada bagian perut akan mengeluarkan butiran telur berwarna kuning pada lubang urogenital dan alat kelamin berwarna kemerah-merahan.

Menurut Burmansyah et al (2013) Ciri-ciri seksual sekunder dan primer ikan betok yaitu ikan betok jantan yaitu memiliki tubuh yang ramping dan panjang, warna badan agak cerah, sirip punggung lebih panjang, bagian bawah perut rata. Jika ikan betok jantan telah matang gonad, apabila di lakukan stripping pada bagian perut, akan keluar cairan sperma berwarna putih susu. Sedangkan ciri-ciri ikan betok betina yaitu memiliki ukuran tubuh yang besar dari ikan betok jantan dan pada bagian perut melebar kesamping, warna badan agak gelap, sirip punggung lebih pendek, bagian bawah perut agak melengkung. Apabila ikan betok betina telah matang gonad dan di stripping pada bagian perut akan keluar butiran telur bewarna kuning dan alat kelamin berwarna kemerah-merahan.

\section{Tingkat Kematangan Gonad (TKG)}

Tingkat kematangan gonad adalah tahap tertentu perkembangan gonad sebelum dan sesudah memijah. Selama proses reproduksi sebagaian besar energi hasil metabolisme ikan akan tertuju untuk perkembangan gonad atau pertumbuhan gonad (Effendie, 2002). Perkembangan gonad ikan sangat berkaitan erat dengan pertumbuhan ikan sehingga faktor internal atau eksternal yang mempengaruhi pertumbuan juga berpengaruh pada perkembangan gonad. Ada dua tahapan perkembangan gonad, yaitu tahap perkembangan gonad ikan menjadi dewasa kelamin (sexually mature) dan tahap pematangan gamet (gamet maturation). Tahap pertumbuhan berlangsung sejak ikan menetas hingga mencapai dewasa kelamin, sedangkan tahap pematangan berlangsung setelah ikan dewasa. Tahap pematangan akan terus berlangsung dan berkesinambungan selama fungsi reproduksi ikan berjalan normal (Lagler, et al., 1977 dalam Mustakim, 2008).

Pada proses reproduksi, sebelum terjadi pemijahan sebagian besar hasil metabolisme tertuju untuk perkembangan gonad. Gonad akan semakin bertambah berat diimbangi dengan bertambah besar ukurannya (Effendie, 2002). Selama perkembangan gonad, oosit dikeliling oleh lapisan sel-sel folikel yang membentuk dua lapisan, yaitu lapisan granulosa disebelah luarnya (Nagahama, 1987 dalam Mustakim, 2008). Sel folikel pada pinggiran oosit berperan penting dalam penyerapan lipoprotein yang berasal dari hati kedalam oosit.

Dari hasil pengamatan pada penelitian di peroleh bahwa perkembangan gonad ikan meningkat pada setiap perlakuan dan kontrol. Diduga perlakuan dengan kandungan protein yang berbeda mampu mempengaruhi tingkat kematangan gonad ikan betok betina dan ditemukan pada hari ke 45 pada perlakuan P.38\% terdapat ikan betok yang telah memasuki TKG IV dengan ciri-ciri gonad berwarna kuning dan telur dan juga ditemukan ikan yang telah mencapai TKG V (Tabel 5) 
dengan ciri-ciri gonad berwarna merah, lembik dan telur tidak tampak. Menurut Effendie (2002) menyatakan bahwa pada proses reproduksi, sebelum terjadi pemijahan sebagian besar hasil metabolisme tertuju untuk perkembangan gonad. Gonad akan semakin bertambah berat diimbangi dengan bertambah besar ukurannya. Acuan pada pengamatan untuk melihat TKG yaitu mengacu pada Effendie (2002) dalam Tester dan Takata (1953) yang menyatakan bahwa TKG IV gonad masak, gonad mengisi $3 / 4$ rongga tubuh. Gonad pada ikan jantan berwarna putih berisi cairan berwarna putih, pada ikan betina berwarna kuning dan telur dapat terlihat. TKG V yaitu salin, gonad jantan berwarna putih kadang-kadang dengan bintik coklat. Gonad betina berwarna merah, lembik dan telur tidak tampak.

\section{Gonado Somatik Indeks (GSI)}

Effendie (2002) menyatakan bahwa

Nilai Gonado Somatik Indeks (GSI) berhubungan dengan Tingkat Kematangan Gonad Ikan (TKG) yang pengamatannya berdasarkan ciri - ciri morfologi kematangan gonad dengan membandingkan perkembangan di dalam dan di luar gonad, atau nilai morfologi yang dikuantatifkan. Berdasarkan hasil pengamatan nilai GSI menunjukkan adanya perbedaan antar perlakuan $(\mathrm{P}<0,05)$ dengan kisaran nilai $16 \% \pm 0.02$ pada perlakuan P.38\% (Gambar 6). Seperti yang telah dikemukakan bahwa dalam menilai perkembangan gonad ikan betina selain dilihat hubungan antara GSI dengan TKG, dapat dihubungkan dengan perkembangan garis tengah telur yang dikandungnya hasil dari pengendapan kuning telur selama veitellogenesis. Berdasarkan hubungan ini akan didapatkan ukuran garis tengah telur yang terbesar pada waktu akan terjadi pemijahan sebagai ukuran telur yang masak ikut dalam pemijahan. Menurut Mustakim (2008), semakin tinggi perkembangan gonad maka perbandingan antara berat tubuh dan gonad semakin besar yang diperlihatkan dengan nili GSI yang besar. Semakin besar nilai GSI, maka dapat dijadikn indicator semakin dekatnya waktu pemijahan.

Pada proses reproduksi, sebelum terjadi pemijahan sebagian besar hasil metabolisme tertuju untuk perkembangan gonad. Gonad akan semakin bertambah berat diimbangi dengan bertambah besar ukurannya (Effendie, 2002). Selama perkembangan gonad, oosit dikeliling oleh lapisan sel-sel folikel yang membentuk dua lapisan, yaitu lapisan granulosa disebelah luarnya (Nagahama, 1987 dalam Mustakim, 2008). Sel folikel pada pinggiran oosit berperan penting dalam penyerapan lipoprotein yang berasal dari hati kedalam oosit. Pada saat proses perkembangan dan pematangan gonad ikan, sebagian besar energi pertumbuhan akan dialihkan dari perkembangan sel somatik menjadi pertumbuhan sel gamet. Sehingga pada saat ikan sudah matang gonad, bobot gonad pada ikan betina beratnya dapat mencapai $10-25 \%$ dari berat tubuhnya, sedangkan pada ikan jantan antara 5-10\% dari berat tubuhnya (Effendie, 1997).

\section{Hepato Somatik Indeks (HSI)}

Nilai Hepato Somatik Indeks (HSI) merupakan nilai kuantitatif yang menggambarkan pertambahan bobot hati seiring dengan perkembangan bobot gonad. Nilai HSI perbandingan antara bobot hati dengan bobot tubuh ikan. Seiring meningkatkan perkembangan gonad menyebabkan nilai HSI juga meningkat dan akan lebih rendah dari nilai IKG pada saat telah matang gonad (Aryani, 2015). Berdasarkan hasil pengamatan pada penelitian nilai HSI menunjukkan adanya perbedaan antar perlakuan $(\mathrm{P}<0,05)$ dengan kisaran $8 \% \pm$ 0.01 pada perlakuan P.38\% (Gambar 7). Pada proses reproduksi, sebelum terjadi pemijahan sebagian besar hasil metabolisme tertuju untuk perkembangan gonad. Gonad akan semakin bertambah berat diimbangi dengan bertambah besar ukurannya (Effendie, 2002). Selama 
perkembangan gonad, oosit dikeliling oleh lapisan sel-sel folikel yang membentuk dua lapisan, yaitu lapisan granulosa disebelah luarnya (Nagahama, 1987 dalam Mustakim, 2008). Sel folikel pada pinggiran oosit berperan penting dalam penyerapan lipoprotein yang berasal dari hati kedalam oosit. Pada saat proses perkembangan dan pematangan gonad ikan, sebagian besar energi pertumbuhan akan dialihkan dari perkembangan sel somatik menjadi pertumbuhan sel gamet.

\section{Tingkat Kebuntingan Ikan}

Tingkat kebuntingan diamati secara morfologi bagian perut induk ikan betina yang membesar, melebar kesamping dan berisi telur yang diketahui dengancara mengurut (stripping) pada bagian berut ikan tersebut. Induk yang bunting adalah induk yang memiliki telur saat dilakukan stripping dan akan mengelurkan telur pada bagian lubang urogenitalnya. Tingkat kebuntingan induk dihitung dengan melakukan pengamatan secara visual melalui pengamatan terhadap bentuk perut dan keberadaan telur dengan dibedah. Perut ikan betok yang bunting terasa halus dan lembek bila diraba. Selain itu, pada bagian perut ikan akan membesar dan melebar kesamping. Apabila dilakukan pengurutan (stripping) pada bagian perut akan mengeluarkan butiran telur pada lubang urogenitalnya. Tidak semua ikan yang bunting siap untuk dibuahi, beberapa ikan saat dibedah telurnya masih muda. Hasil pengamatan pada hari ke 45 menunjukkan pada semua perlakuan dan kontrol menujukan adanya kebuntingan pada ikan betok ditandai dengan perut ikan betok yang bunting terasa halus dan lembek apabila diraba. Selain itu, pada bagian perut ikan akan membesar dan melebar kesamping. Apabila dilakukan pengurutan (stripping) pada bagian perut akan mengeluarkan butiran telur pada lubang urogenitalnya. Berdasarkan hasil ini, pemberian pakan buatan berbahan baku keong mas (Pomacea canalicuata) pada perlakuan dan kontrol menggunakan pakan komersil 781-1 diduga mempengaruhi proses rematurasi kebuntingan ikan perlakuan dan kontrol.

\section{Fekunditas}

Fekunditas merupakan jumlah telur masak sebelum dikeluarkan pada waktu ikan memijah (Effendie 2002). Fekunditas merupakan ukuran yang paling umum digunakan untuk mengukur potensi produksi pada ikan karena relatif mudah dihitung. Fekunditas lebih sering dihubungkan dengan panjang daripada dengan berat, karena panjang penyusutannya relatif kecil tidak seperti berat yang dapat berkurang dengan mudah (Effendie 2002). Hasil penelitian menunjukkan bahwa fekunditas memiliki hubungan dengan bobot gonad dimana nilai $\mathrm{R}^{2}=0,513$ (Gambar 8). dan bobot tubuh dimana nilai $\mathrm{R}^{2}=0,34($ Gambar 9), hal ini sesuai dengan literatur. Fekunditas merupakan jumlah telur yang dihasilkan oleh ikan betina. Ada beberapa pengertian fekunditas antara lain fekunditas individu, fekunditas relatif, dan fekunditas total. Menurut Nikolsky (1963) dalam Effendie (2002), fekunditas individu adalah jumlah telur dari generasi tahun itu yang dikeluarkan pada tahun itu pula. Fekunditas relatif adalah jumlah telur persatuan berat atau panjang, sedangkan fekunditas total diartikan sebagai jumlah telur yang dihasilkan oleh ikan selama hidupnya. Ikan-ikan yang tua dan besar ukurannya mempunyai fekunditas relatif lebih kecil. Umumnya fekunditas relatif lebih tinggi dibanding dengan fekunditas individu. Fekunditas relatif akan menjadi maksimum pada golongan ikan yang masih muda.

Berdasarkan hasil penelitian yang telah dilakukan bahwa ikan Betok betina memiliki fekunditas dengan jumlah $509 \pm$ 4.686 butir telur per ikan dengan tingkat kematangan gonadnya sudah memasuki fase ke 4 dengan ciri-ciri warna telur sudah kekuningan dan butiran telur terlihat jelas. Hasil penelitian menunjukan berbeda dengan literatur yang menyebutkan bahwa 
ikan betok dengan kisaran bobot tubuh 15 sampai 110 gram dan bobot gonad 2,42 sampai 15,96 gram mempunyai jumlah telur (fekunditas) antara 4.882 hingga 19.248 butir. Hal ini dikarenakan ikan yang digunakan pada penelitian yaitu ikan betok hasil tangkapan di alam dengan ukuran yang tidak seragam namun memiliki fekunditas yang tinggi.

Nikolsky (1963) dalam Effendie (2002) menyatakan bahwa fekunditas pada ikan disesuaikan dengan kondisi lingkungannya. Jika ikan hidup di habitat yang banyak ancaman predator maka jumlah telur yang dihasilkan akan besar atau fekunditas semakin tinggi, sedangkan ikan yang hidup di habitat dengan sedikit predator akan memiliki jumlah telur yang lebih sedikit. Beberapa faktor yang berperan terhadap jumlah telur yang dihasilkan oleh ikan betina yaitu fertilitas, frekuensi pemijahan, perlindungan induk, ukuran telur, ukuran ikan, kondisi lingkungan, makanan, dan kepadatan populasi.

\section{Pertumbuhan \\ Pertumbuhan Bobot Mutlak dan Pertumbuhan Panjang Mutlak}

Effendie (2002) menyatkan bahwa pertumbuhan dapat dirumuskan sebagai pertambahan ukuran panjang atau berat dalam suatu waktu, sedangkan pertumbuhan bagi populasi sebagai pertambahan jumlah. Sebenarnya, pertumbuhan itu merupakan proses biologis yang kompleks dimana banyak faktor mempengaruhinya. Pertumbuhan dalam individu ialah pertambahan jaringan akibat dari pembelahan sel secara mitosis. Hal ini terjadi apabila ada kelebihan input energi dan asam amino (protein) berasal dari makanan. Pertumbuhan mutlak ialah ukuran rata-rata ikan pada umur tertentu, seperti ukuran panjang rata-rata ikan berumur satu tahun atau berat rata-rata ikan berumur tiga tahun dan sebagainya (Effendie, 1997).

Berdasarkan hasil pengamatan pada penelitian pertumbuhan bobot mutlak ikan betok yang diberikan pakan buatan berbahan baku tepung keong mas menunjukkan pada pengamatan kontrol rata-rata hasil pengamatan yaitu 5.21, P.32\% yaitu 5.67, P.34 yaitu 6.68, P.3\% yaitu 6.13 dan pada pengamatan P.38\% yaitu 7.53.

Sedangkan pada pertumbuhan panjang mutlak dari pengamatan pertumbuhan panjang mutlak yaitu; pada pengamatan kontrol hasil rata-rata nilai pengamatan yaitu 6.14 , P.32\% yaitu 7.03 , P.34 yaitu 6.93, P.36\% yaitu 7.12 dan pada pengamatan P.38\% yaitu 8.02. Pengamatan pertumbuhan bobot mutlak menunjukkan perbedaan $(\mathrm{P}<0,05)$ dengan kisaran nilai $7.53 \mathrm{~g} \pm 0.94$ pada perlakuan P.38\%. dan pada pengamatan pertumbuhan panjang mutlak menunjukkan perbedaan antar perlakuan $(\mathrm{P}<0,05)$ dengan kisaran nilai $8.02 \mathrm{~cm} \pm 0.75$ pada perlakuan P. $38 \%$.

Hasil ini berbeda dengan penelitian yang dilakukan Hidayat et.al (2013) menyatakan bahwa analisis ragam menunjukkan penggunaan tepung keong mas dalam pakan tidak berpengaruh nyata terhadap pertumbuhan bobot mutlak dan pertumbuhan panjang mutlak benih ikan gabus. Meskipun secara ANOVA tidak berpengaruh nyata, namun pertumbuhan bobot mutlak tertinggi terdapat pada perlakuan $50 \%$ tepung keong mas diperoleh sebesar 4,96 g, sedangkan pertumbuhan bobot mutlak terendah terdapat pada perlakuan 37,5 \% tepung keong mas yaitu sebesar 2,97 g. Untuk pertumbuhan panjang mutlak tertinggi terdapat pada perlakuan $0 \%$ tepung keong mas, dan $50 \%$ tepung keong mas yaitu sebesar panjang $0,9 \mathrm{~cm}$, sedangkan pertumbuhan panjang mutlak terendah terdapat pada perlakuan $25 \%$ tepung keong mas yaitu sebesar $0,4 \mathrm{~cm}$.

Prihadi (2007), menyatakan pertumbuhan dipengaruhi oleh beberapa faktor yaitu faktor dari dalam dan factor dari luar, adapun faktor dari dalam meliputi sifat keturunan, ketahanan terhadap penyakit dan kemampuan dalam memanfaatkan makanan, sedangkan faktor 
dari luar meliputi sifat fisika, kimia dan biologi perairan. Faktor makanan dan suhu perairan merupakan faktor utama yang dapat mempegaruhi pertumbuhan ikan.

\section{Laju Pertumbuhan Harian}

Pertumbuhan harian berfungsi untuk menghitung persentase pertumbuhan berat ikan per hari. Hasil penelitian menunjukkan bahwa hasil pengamatan laju pertumbuhan harian bahwa perlakuan yang diberikan pakan buatan berbahan baku tepung keong mas pada pengamatan laju pertumbuhan harian menunjukkan perbedaan antar perlakuan $(\mathrm{P}<0,05)$ pada P.32\% dan P.34\% dengan kisaran nilai $1.57 \mathrm{~g} \pm 0.001$ dan $1.40 \mathrm{~g} \pm 0.002$. Menurut Handajani dan Widodo (2010) pertumbuhan ikan yang baik, perlu didukung dengan pemberin makanan yang cukup mengandung protein, lemak dan karbohidarat serta vitamin dan mineral.

\section{Kualitas Air}

Salah satu faktor yang dapat mempengaruhi pertumbuhan ikan budidaya adalah kualitas air, terdiri dari oksigen terlarut (DO), suhu dan $\mathrm{pH}$. Oksigen terlarut (DO) merupakan salah satu parameter peubah kualitas air yang paling kritis pada budidaya ikan. Kondisi oksigen (DO) terlarut dalam air merupakan indikator kualitas air. Penurunan DO merupakan indikator dini terhadap perubahan kualitas air (Syofyan et al. 2011).

Hasil pengukuran oksigen terlarut selama penelitian yaitu berkisar $5.6 \mathrm{ppm}$, sesuai dengan litelatur yang menyatakan bahwa oksigen terlarut dalam budidaya ikan tidak boleh kurang dari 5 ppm, hal ini dikarenakan ikan memerlukan oksigen terlarut untuk proses pembakaran makanan sehingga dapat menghasilkan aktivitas, berenang, pertumbuhan dan reproduksi (Zonneveld et al. 1991).

Perubahan suhu dalam wadah pemeliharaan di pengaruhi oleh sinar matahari yang langsung masuk kedalam wadah pemeliharaan. Perubahan suhu dapat mempengaruhi metabolisme tubuh dalam ikan (Augusta, 2016). Hasil pengukuran parameter suhu yang dilakukan selama penelitian yaitu berkisar $30^{\circ} \mathrm{C}$. Hal ini dikarenakan tingginya intensitas cahaya yang masuk langsung ke dalam tempat penelitian, karena penelitian dilakukan pada tempat yang tertutup dan juga penelitian dilakukan ketika musim kemarau sehingga mempengaruhi suhu air dalam wadah pemeliharaan. Hasil pengamatan suhu pada penelitian sesuai dengan literatur yang diacu pada Akbar (2012) yang menyebutkan bahwa umumnya di alam ikan betok tumbuh normal pada kisaran kualitas air untuk suhu $24-34^{\circ} \mathrm{C}$.

Hasil pengukuran $\mathrm{pH}$ atau derajat keasaman air pada penelitian yaitu berkisar antara $6.24-6.73$, hal ini sesuai dengan Akbar (2012) yang menyatakan bahwa umunya di alam ikan betok tumbuh normal pada derajat keasaman atau $\mathrm{pH}$ berkisar 48. Ikan betok tahan terhadap kekeringan dan kadar oksigen yang rendah. Kadangkadang tahan hidup satu minggu tanpa air, bahkan mampu hidup di lumpur yang mengandung sedikit air selama 1-2 bulan. Ikan betok memiliki sifat biologis yang lebih menguntungkan bila dibandingkan dengan jenis ikan air tawar lainnya dalam hal pemanfaatan air sebagai media hidupnya. Salah satu kelebihan tersebut adalah bahwa ikan betok memiliki labirin yang berfungsi sebagai alat pernafasan tambahan.

Amoniak dalam media budidaya berbahaya bagi ikan jika terdapat dalam konsentrasi yang tinggi. Amoniak dalam media pemeliharaan berasal dari ekskresi ikan melalui insang, perombakan sisa metabolisme, serta dari perombakan sisa pakan dalam media pemeliharaan. Nilai amoniak yang dihasilkan selama penelitian berfluktuasi dan berada pada kisaran 0.16$0.29 \mathrm{mg} / \mathrm{L}$. Nilai tersebut masih dapat ditoleransi oleh ikan. Menurut Boyd (1990) dalam Catur (2011), kisaran konsentrasi amoniak dalam pemeliharaan ikan adalah kurang dari $0,1 \mathrm{mg} / \mathrm{L}$. 


\section{KESIMPULAN}

Adapun kmpulan dari hasil penelitian adalah sebagai berikut :

1. Pemberian pakan buatan berbahan baku keong mas dapat meningkatkan performa reproduksi ikan betok betina. Hal ini dapat dilihat dari meningkatnya nilai tingkat kematangan gonad ikan betok betina. Pemberian pakan buatan berbahan baku tepung keong mas dengan kandungan protein pakan 38\% pada hari ke-45 mampu meningkatkan nilai GSI $16 \% \pm 0.02$ dan HSI $8 \% \pm 0.01$.

2. Pemberian pakan buatan berbahan baku tepung keong mas dapat meningkatkan pertumbuhan ikan betok. Hal ini dapat dilihat dari adanya peningkatan dari pertumbuhan bobot mutlak dengan kisaran $7.53 \mathrm{~g} \pm 0.94$ pada perlakuan $\mathrm{P} .38 \%$, panjang mutlak dengan kisaran $8.02 \mathrm{~cm} \pm 0.75$ pada perlakuan P.38\% dan laju pertumbuhan harian dengan kisaran $1.57 \mathrm{~g} \pm 0.001$ dan $1.40 \mathrm{~g} \pm 0.002$ pada perlakuan P.34\% dan P.36\%.

3. Pemberian pakan buatan berbahan baku keong mas dapat meningkatkan kematangan gonad ikan. Nilai tingkat kematangan gonad ikan betok pada awal penelitian adalah TKG II, setelah dilakukan pemberian pakan perlakuan menggunakan pakan buatan berbahan baku keong mas mampu meningkatkan nilai tingkat kematangan gonad ikan mencapai pada tahap TKG IVdan V. Hasil fekunditas pada penelitian yaitu berkisar antara 509 - 4.686 butir.

\section{DAFTAR PUSTAKA}

Akbar, J. 2012. Ikan Betok Budidaya dan Peluang Bisnis. Eja Publisher: Yogyakarta.

Aryani M.N. 2015. Induksi Pematangan Gonad Angguilla bicolor Ukuran 100150 gram Secara Hormonal Menggunakan PMSG, AD dan MT.
[Tesis]. Bogor: Institut Pertanian Bogor.

Catur, W.P. 2011. Pertumbuhan dan Kelangsungan Hidup Larva Ikan Betok Anabas testudineus Bloch Selama 30 Hari Pemeliharaan dengan Padat Penebaran Awal 10, 20, dan 30 Larva/Liter. [ Skripsi ]. Bogor: Institut Pertanian Bogor.

Departemen Kelautan dan Perikanan Tahun 2005. Laporan Statistik Kelautan dan Perikanan Tahun 2005.

DKP Provinsi Kepulauan Bangka Belitung. 2017. Laporan Kinerja Dinas Kelautan dan Perikanan Provinsi Kepulauan Bangka Belitung Tahun 2016. http://DKP Provinsi-KepulauanBangka-Belitung (diakses 17 November 2018).

Effendi, I., H.J. Bugri., dan Widarni. 2006. Pengaruh padat penebaran terhadap kelangsungan hidup dan pertumbuhan benih ikan gurami Osphronemus gouramy Lac. Ukuran $2 \mathrm{~cm}$. Jurnal Akuakultur Indonesia. 5(2) : 127-135.

Effendie, M.I. 1979. Metoda Biologi Perikanan. Yayasan Dewi Sri Cikuray : Bogor.

Effendie, M.I. 2002. Biologi Perikanan. Yayasan Pustaka Nusatama : Bogor.

Handajani, H. dan Widodo, W. 2010. Nutrisi Ikan. UMM Press: Malang.

Hanifah, SS. 2010. Rekayasa Rematurasi Ikan Patin Siam Pangasianodon hypophthalmus dengan Penyuntikan Hormon Pmsg dan Hcg Serta Penambahan Vitamin Mix 300 $\mathrm{Mg} / \mathrm{Kg}$ Pada Pakan. [Skripsi]. Institut Pertanian Bogor : Bogor.

Hidayat, D., Dwi, A.S dan Yulisman. 2013. Kelangsungan hidup, pertumbuhan dan efisiensi pakan ikan gabus (Channa Striata) yang diberi pakan berbahan baku tepung keong mas (Pomacea Sp). Jurnal Rawa Akuakultur Indonesia. 1(2) : 161-172.

Huisman, E.A. 1987. The principles of fish culture production. Departemen of Aquaculture. Wageningen University. Netherland. 
Lagler, K. F. J. E. Bardach, R. R. Miller. Dan D. M. Passino. 1977. Ichtiology. John Wiley and Sons, Inc. New York. 505 hal.

Margono, T., Detty, S dan Sri H. 1993. Panduan Teknologi Pangan. Pusat Infromasi Wanita dalam Pembangunan. PDII - LIPI. Jakarta.

Mustakim , M. 2008. Kajian Kebiasaan Makanan dan Kaitannya dengan Aspek Reproduksi Ikan Betok (Anabas testudineus Bloch) pada Habitan yang Berbeda di Lingkungan Danau Melintang Kutai Kartanegara Kalimantan Timur. [Tesis]. Sekolah Pascasarjana Institut Pertanian Bogor : Bogor.

National Research Concil. 2001. Nutrient Requitrements for Dairy Cattle $7^{\text {th }}$
Revedition. National Academy Press : Washington DC.

Prihadi, D.J. 2007. Pengaruh jenis dan waktu pemberian pakan terhadap tingkat kelangsungan hidup dan pertumbuhan kerapu macan (Epinephelus fuscoguttatus) dalam keramba jarring apung di Balai Budidaya Laut Lampung. Fakultas Perikanan dan Ilmu Kelautan Universitas Padjadjaran. Bandung. Jurnal Akuakultur Indonesia 493-9531.

Syofyan I., Usman, dan Nasution P. 2011. Studi Kualitas Air untuk Kesehatan dalam Budidaya Perikanan pada Aliran Sungai Kampar Kiri. Jurnal Perikanan dan Kelautan. 16,1 (2): 6470. 